\title{
DAYA BELI MASYARAKAT TERHADAP BAHAN PANGAN POKOK DI KABUPATEN HALMAHERA TENGAH
}

\author{
Muhammad Zais M, Samiun dan Nurdin I Muhammad \\ Fakultas EKonomi - Universitas Khairun \\ Email : mzaissamiun@gmail.com
}

\begin{abstract}
This study aims to: (1), Knowing the share of expenditure, the progress of prices of staple food and people's income in Central Halmahera Regency, (2), Analyzing the level of people's purchasing power with an indicator of the ratio of income to prices of staple foods in Central Halmahera Regency, and (3), Analyze the level of people's purchasing power with an indicator of the ratio of income to the index of staple food prices in Central Halmahera Regency. The results of the analysis show that the expenditure of community households in Central Halmahera Regency is specifically allocated to fulfill the consumption of fresh rice and fish, followed by consumption of flour, sugar and cooking oil. While the allocation of expenditures for consumption of staple-sourced staple foods includes chicken, milk, eggs and beef is still very low. The price of staple food in Central Halmahera Regency during the observation period of 2009 until 2018 in January - March, tends to increase in the range of 2\% - 12\%. Whereas on the other hand, the level of income of the community only changes in the range of 5\% - 7\%, with the highest income enjoyed by employees and entrepreneurs and conversely the lowest income is felt by farmers. The purchasing power of people in Central Halmahera Regency with an indicator of the ratio of income to each of the staple food prices tends to fluctuate but has experienced significant improvements in 2018 compared to 2009, except for the purchasing power measured as equal to beef consumption. The purchasing power equivalent to beef consumption has decreased to $22.32 \%$ because the percentage increase in income is less able to compensate for the increase in beef prices. Measured by the income ratio indicator on the basic food price index, people's purchasing power also showed an improvement in 2018 compared to 2009, but that only happened to farmers, construction workers, and civil servants groups I/II. When compared to 2017, public purchasing power in 2018 as a whole decreased by 12.38\%. The purchasing power level of people in Central Halmahera Regency from the lowest ranking in sequence is felt by groups of farmers, followed by construction workers, civil servants groups I/II, entrepreneurs and employees.
\end{abstract}

Key Words : Staple Food, People's Purchasing Power, Prices, Income.

PENDAHULUAN

$\begin{array}{rrrr} & \text { Pelaksanaan pembangunan masyarakat yang sebesarnya. Diantara } & \text { man } \\ \text { pada prinsipnya adalah untuk berbagai pilihan, taraf kesejahteraan }\end{array}$


Jurnal Penelitian Humano, Vol. 9 No. 2 Edisi November 2018

masyarakat dalam pembangunan yang terpenting adalah peluang hidup (longevity), pengetahuan (knowledge), serta standar hidup layak (decent living). Standar hidup layak atau lebih dikenal dengan daya beli adalah komponen dari indeks pembangunan manusia yang cukup sulit untuk di tingkatkan (Jum'at, 2008). Dalam cakupan lebih luas, standar hidup layak menggambarkan tingkat kesejahteraan yang dinikmati oleh penduduk sebagai dampak semakin membaiknya ekonomi. Kaitannya dengan daya beli masyarakat terhadap bahan pangan pokok, terdapat berbagai variabel ekonomi yang sangat mempengaruhi diantaranya adalah tingkat harga pangan, tingkat pendapatan serta alokasi pengeluaran terhadap bahan pangan. Harga pangan merupakan salah satu aspek dalam ekonomi pangan yang selalu dimonitor oleh pemerintah secara berkala karena bila terjadi kenaikan harga yang tajam berpotensi menimbulkan gejolak sosial.

Menurut Rachman (2005), ada lima tujuan yang ingin dicapai pemerintah terkait dengan kebijakan harga pangan, yaitu 1) meningkatkan pendapatan petani, 2) meningkatkan insentif kepada petani kecil agar tetap memproduksi bahan pangan, 3) mengurangi ketergantungan akan impor dan mencapai swasembada pangan, 4) menjaga kestabilan harga dan 5) menaruh perhatian pada daya beli masyarakat sehingga kebutuhan pangan terjamin. Terkait daya beli, kenaikan harga pangan akan berdampak lebih besar terhadap kelompok masyarakat berpendapatan tetap yang rendah (miskin) sehingga akan berisiko tinggi terhadap nutrisi dan kerawanan pangan (food insecurity). Lebih lanjut, menurut Firdaus (2017), kebanyakan negara di dunia menghadapi persoalan pangan hanya karena variasi musiman. Ada periode waktu tertentu dimana produksi berkurang. Sedangkan untuk kasus Indonesia, selain variasi musiman, variasi geografis karena sebagai negara kepulauan juga turut mempengaruhi persoalan pangan. Pada beberapa komoditas, meskipun produksi kadang cukup namun persoalan distribusi juga menyebabkan di beberapa daerah mengalami kelangkaan yang kemudian sangat 
Jurnal Penelitian Humano, Vol. 9 No. 2 Edisi November 2018

berimplikasi terhadap tingkat harga pangan di pasar domestik.

Selain harga, pendapatan menjadi ukuran utama untuk melihat sejauhmana daya beli masyarakat meningkat atau tidak, Pendapatan digunakan pula untuk mengukur sejauhmana pendapatan tersebut dapat memenuhi kebutuhan terhadap bahan pangan seperti membeli beras, daging, ikan, dan lainnya. Perubahan tingkat pendapatan masyarakat dan besaran harga barang dan jasa khususnya harga pangan dalam perekonomian daerah tentunya sangat berimplikasi terhadap alokasi pengeluaran perkapita. Data yang dipublikasikan oleh Badan Pusat Statistik Provinsi Maluku Utara (2007), menjelaskan bahwa pengeluaran rata-rata perkapita sebulan di Kabupaten Halmahera Tengah lebih banyak teralokasikan untuk kelompok makanan yakni Rp. 449.756.- atau 54,76, sedangkan untuk kelompok bukan makanan rata-rata sebesar Rp. 371.560.- atau 45,24\%. Alokasi atau pangsa pengeluaran rumah tangga per kapita mencerminkan kualitas standar hidup layak di suatu daerah yang ditunjukkan oleh tercapainya kebutuhan dasar manusia. Rumah tangga yang memiliki pangsa pengeluaran yang lebih besar untuk konsumsi makanan mengindikasikan rumah tangga tersebut berpenghasilan rendah. Dengan kata lain, rumah tangga/keluarga akan semakin sejahtera apabila persentase pengeluaran untuk makanan jauh lebih kecil dibandingkan pengeluaran untuk bukan makanan.

Kondisi lain yang juga mempengaruhi indeks daya beli masyarakat terhadap bahan pangan pokok, bahwa dengan karakteristik geografis wilayah kepulauan berimplikasi terhadap pola distribusi dan ketersediaan bahan pangan pokok yang akhirnya sangat berdampak terhadap tingkat harga pangan pokok di pasar domestik. Selain itu, fakta menunjukkan bahwa sebagaian besar bahan pangan pokok yang menjadi makanan utama masyarakat masih sangat bergantung pada pangan impor dari luar wilayah. Artinya bahwa dengan kapasitas produksi bahan pangan lokal yang masih terbatas maka ketika terjadi kenaikan harga bahan pangan impor dan biaya transportasi akan sangat berdampak http://ejournal.unkhair.ac.id/index.php/humano 314 
Jurnal Penelitian Humano, Vol. 9 No. 2 Edisi November 2018

terhadap naikknya harga bahan pangan

dalam pasar domestik yang kemudian berimplikasi terhadap indeks daya beli masyarakat, terutama ketika peningkatan harga tersebut jauh lebih besar dari perubahan pendapatan masyarakat.

Mengingat hal tersebut, analisis mengenai dampak dinamika harga bahan pangan pokok terhadap daya beli perlu dilakukan. Pendekatan yang digunakan dalam analisis ini adalah pendekatan daya beli dengan membandingkan dinamika pendapatan dan harga bahan pangan pokok, khususnya bagi kelompok masyarakat yang berpendapatan rendah dan tetap. Dengan pendekatan tersebut diharapkan dapat diperkirakan tingkat daya beli sebagai salah satu indikator kesejahteraan masyarakat. Tingkat daya beli yang dimaksud adalah tingkat daya daya beli masyarakat yang dipengaruhi oleh tingkat pendapatan atau upah dibandingkan dengan harga-harga barang dan jasa dan tingkat pendapatan. Dari hasil kajian ini diharapkan akan terlihat gambaran bagaimana perubahan daya beli seiring dengan perubahan harga bahan pangan pokok tersebut. Adapun penelitian ini bertujuan untuk : (1). Mengetahui pangsa pengeluaran, perkembangan harga bahan pangan pokok dan pendapatan masyarakat di Kabupaten Halmahera Tengah, (2). Menganalisis tingkat daya beli masyarakat dengan indikator rasio pendapatan terhadap harga pangan pokok di Kabupaten Halmahera Tengah, dan (3). Menganalisis tingkat daya beli masyarakat dengan indikator rasio pendapatan terhadap indeks harga pangan pokok di Kabupaten Halmahera Tengah.

TINJAUAN KONSEPTUAL Pengertian dan Pengelompokan Pangan Pokok

Kebutuhan paling mendasar bagi sumber daya manusia suatu bangsa adalah pangan. Ketersediaan pangan dalam jumlah dan kualitas yang cukup, diperlukan dalam mencapai ketahanan pangan. Faktor lain yang merupakan faktor penting dalam mencapai ketahanan pangan adalah tersedianya dan terdistribusinya pangan yang terjangkau dari sisi harga dan aman dikonsumsi masyarakat untuk mencukupi kebutuhan energi dalam aktivitas sehari-hari (Saliem et al, 2002). Pangan dinilai penting 
Jurnal Penelitian Humano, Vol. 9 No. 2 Edisi November 2018

(Nurkhayani, 2009) karena kenaikan harga pangan dapat menyebabkan penurunan konsumsi kalori dan protein yang besar.

Dalam UU Pangan yang baru yaitu UU No, 18 Tahun 2012 (Setneg, 2012) tentang Pangan, pengertian pangan lebih diperluas terutama ruang lingkup jenis pangannya. Dalam UU Pangan tersebut, pangan didefinisikan segala sesuatu yang berasal dari sumber hayati, produk pertanian, perkebunan, kehutanan, perikanan, peternakan, perairan, dan air, baik yang diolah maupun tidak diolah diperuntukkan sebagai makanan atau minuman bagi konsumsi manusia, termasuk bahan tambahan pangan, bahan baku pangan, dan bahan lainnya yang digunakan dalam proses penyimpanan, pengolahan, dan atau pembuatan makanan dan minuman. Pada UU UU No, 18 Tahun 2012, pangan pokok didefinisikan secara eksplisit, Pangan Pokok berdasarkan UU ini adalah pangan yang diperuntukkan sebagai makanan utama sehari-hari sesuai dengan potensi sumber daya dan kearifan lokal. FAO (2010) mendefinisikan pangan pokok sebagai pangan yang dikonsumsi secara rutin pada kuantitas tertentu yang menjadi bagian dominan dalam pola makan dan merupakan sumber asupan energi dan gizi utama yang dibutuhkan. Pangan pokok memang tidak dapat memenuhi seluruh kebutuhan nutrisi karena tubuh membutuhkan variasi pangan lain (Ariani, 2010).

Penentuan jenis pangan yang dikonsumsi sangat tergantung kepada beberapa faktor, di antaranya jenis tanaman penghasil bahan pangan pokok yang biasa ditanam di daerah serta tradisi yang diwariskan oleh budaya setempat. Perilaku konsumsi pangan masyarakat dilandasi oleh kebiasaan makan (food habit) yang tumbuh dan berkembang dalam lingkungan keluarga melalui proses sosialisasi (Hidayah, 2011). Menurut Badan Pusat Statistik (BPS, 2011), bahan pangan dibagi ke dalam sembilan kelompok yang meliputi (1) padi-padian (beras, jagung, terigu), (2) umbi-umbian (singkong, ubi jalar, kentang, sagu, umbi lainnya),(3) pangan hewani (daging ruminansia, daging unggas, telur, susu, ikan), (4) minyak dan lemak (minyak kelapa, minyak sawit, minyak lainnya), (5) http://ejournal.unkhair.ac.id/index.php/humano 316 
Jurnal Penelitian Humano, Vol. 9 No. 2 Edisi November 2018

buah/biji berminyak (kelapa, kemiri), (6) kacang-kacangan (kedelai, kacang tanah, kacang hijau, kacang lain), (7) gula (gula pasir, gula merah, (8) sayuran dan buah (sayur, buah), (9) lain-lain (minuman, bumbu-bumbuan). Selanjutnya menurut Surat Keputusan Menko Perekonomian No, Kep28/M,EKON/05/2010 Tahun 2010 tentang Tim Koordinasi Stabilisasi Pangan Pokok, Bapok meliputi beras, gula, minyak goreng, terigu, kedelai, daging sapi, daging ayam, dan telur ayam.

\section{Konsep Harga Pangan}

Menurut Hanafie (2010), harga merupakan cerminan dari interaksi antara penawaran dan permintaan yang bersumber dari sektor rumah tangga (sebagai sektor konsumsi) dan sektor industri (sebagai sektor produksi). Sebagai cerminan kekuatan-kekuatan pasar, pemerintah tidak selalu dapat mengendalikan mekanisme pembentukan harga kepada kekuatan pasar atas suatu komoditi tertentu, Kebijakan harga didefinisikan sebagai campur tangan pemerintah, baik secara langsung maupun tidak laangsung untuk mengubah harga-harga yang diterima dan dibayakan oleh para pelaku pasar (produsen dan konsumen).

Kaitannya dengan pangan, kebijakan harga pangan bertujuan untuk mencapai salah satu atau kombinasi dari tujuan-tujuan yaitu (Hanafie, 2010): 1). Kontribusi terhadap anggaran pemerintah, 2). Pertumbuhan devisa negara, 3). Mengurangi ketidakstabilan harga, 4). Memperbaiki distribusi pemasaran dan alkasi sumber daya, 5). Memberikan arah produksi, serta meningkatkan taras swasembada dan serat-seratan, dan 6). Meningkatkan pendapatan dan taraf kesejaheraan penduduk,

Keadaan produsen dikatakan lebih baik apabila surplus produsen lebih tinggi dan sebaliknya keadaan konsumen dikatakan lebih baik bila surplus konsumen mengalami kenaikan. Beberapa analisis terhadap kebijakan harga didasarkan atas surplus produsen dan konsumen (Hanafie, 2010) diantaranya: 1). Harga rendah untuk produsen dan konsumen: produsen bebas mengambil keputusan, 2). Harga rendah untuk produsen dan konsumen: tingkat produksi dipaksakan pada produsen, http://ejournal.unkhair.ac.id/index.php/humano 317 
Jurnal Penelitian Humano, Vol. 9 No. 2 Edisi November 2018

3). Harga rendah untuk konsumen: harga produsen yang tidak terdistorsi, 4). Harga rendah konsumen: harga produsen yang dilindungi, 5). Harga tinggi untuk konsumen dan produsen: keadaan impor, dan 6). Harga tinggi untuk konsumen dan produsen: keadaan ekspor.

\section{Teori Pendapatan}

Menurut Sukirno

pendapatan adalah jumlah penghasilan yang diterima oleh penduduk atas prestasi kerjanya selama satu periode tertentu, baik harian, mingguan, bulanan, ataupun tahunan, Beberapa klasifikasi pendapatan antara lain :

1. Pendapatan pribadi, yaitu: semua jenis pendapatan yang diperoleh tanpa memberikan suatu kegiatan apapun yang diterima penduduk suatu negara.

2. Pendapatan disposible, yaitu: pendapatan pribadi dikurangi pajak yang harus dibayarkan oleh para penerima pendapatan, sisa pendapatan yang siap dibelanjakan inilah yang dinamakan pendapatan disposible.

3. Pendapatan nasional, yaitu: nilai seluruh barang-barang jadi dan jasa-jasa yang diproduksikan oleh suatu negara dalam satu tahun.

Menurut Sobri pendapatan disposible adalah suatu jenis penghasilan yang diperoleh seseorang yang siap dibelanjakan atau dikonsumsikan. Menurut Teori Milton Friedman bahwa pendapatan masyarakat dapat digolongkan menjadi dua, yaitu pendapatan permanen (permanent income) dan pendapatan sementara (transitory income). Pendapatan permanen dapat diartikan pendapatan yang selalu diterima pada periode tertentu dan dapat diperkirakan sebelumnya, sebagai contoh adalah upah dan gaji.

\section{Faktor-Faktor Yang Mempengaruhi} Daya Beli Masyarakat

Daya beli diartikan sebagai kemampuan membayar untuk memperoleh barang yang dikehendaki atau diperlukan. Daya beli merupakan kemampuan seseorang, keluarga atau masyarakat untuk memperoleh suatu barang/jasa guna memenuhi kebutuhan hidup. $\quad$ Faktor-faktor yang mempengaruhi daya beli masyarakat yaitu (Sukardi, 2009): 
Jurnal Penelitian Humano, Vol. 9 No. 2 Edisi November 2018

1. Tingkat Pendapatan. Pendapatan merupakan suatu balas jasa dari seseorang atas tenaga atau pikiran yang telah disumbangkan, biasanya berupa upah atau gaji, Makin tinggi pendapatan seseorang makin tinggi pula daya belinya dan semakin beraneka ragam kebutuhan yang harus dipenuhi, dan sebaliknya.

2. Tingkat Pendidikan. Makin tinggi pendidikan seseorang makin tinggi pula kebutuhan yang ingin dipenuhinya. Contohnya seorang sarjana lebih membutuhkan computer dibandingkan seseorang lulusan sekolah dasar.

3. Tingkat Kebutuhan. Kebutuhan setiap orang berbeda-beda. Seseorang yang tinggal di kota daya belinya akan lebih tinggi jika dibandingkan dengan yang tinggal di desa.

4. Kebiasaan Masyarakat. Di zaman yang serba modern muncul kecenderungan konsumerisme didalam masyarakat. Penerapan pola hidup ekonomis yaitu dengan membeli barang dan jasa yang benar-benar dibutuhkan, maka secara tidak langsung telah meningkatkan kesejahteraan hidup.

5. Harga Barang. Jika harga barang naik maka daya beli konsumen cenderung menurun sedangkan jika harga barang dan jasa turun maka daya beli konsumen akan naik. Hal ini sesuai dengan hokum permintaan.

6. Mode. Barang-barang yang baru menjadi mode dalam masyarakat biasanya akan laku keras di pasar sehingga konsumsi bertambah. Dengan demikian mode dapat mempengaruhi konsumsi.

Harga merupakan indikator penting dalam ekonomi, terutama jika menyangkut bahan pangan. Penelitian mengenai hubungan antara harga pangan dengan daya beli masyarakat sudah banyak dilakukan, Ivanic dan Martin (2008) melakukan studi yang difokuskan pada pengaruh kenaikan harga bapok di negara-negara miskin terhadap tingkat kemiskinan. Di satu sisi, peningkatan harga akan meningkatkan pendapatan bagi mereka yang menjual produk tersebut, Sedangkan di sisi lain, konsumen akan dirugikan. Efek kenaikan harga tersebut terhadap kemiskinan http://ejournal.unkhair.ac.id/index.php/humano 319 
Jurnal Penelitian Humano, Vol. 9 No. 2 Edisi November 2018

bergantung pada keseimbangan antara dua sisi tersebut. Namun demikian, hasil studi menunjukkan bahwa dalam jangka pendek kenaikan harga bapok meningkatkan kemiskinan secara substansial.

Instabilitas dan kenaikan harga pangan merupakan faktor penting yang mempengaruhi daya beli masyarakat. Frankenberg, Thomas dan Beegle (1999) melakukan studinya saat Indonesia mengalami krisis ekonomi. Tahun 1998 merupakan titik puncak krisis ekonomi dimana perekonomian menyusut $15 \%$ dan inflasi meroket sebesar $80 \%$. Hal tersebut tentu berpengaruh terhadap pengeluaran rumah tangga untuk berbagai barang dan jasa. Hasil studi menunjukkan bahwa rumah tangga di perkotaan mengalami penurunan konsumsi 10-15\% lebih besar dibandingkan rumah tangga di pedesaan. Pengaruh instabilitas harga terhadap daya beli juga menjadi latar belakang studi yang dilakukan Galtier (2009). Instabilitas harga yang tinggi di negara berkembang akan berakibat pada ketahanan pangan, bukan hanya dalam jangka pendek (akses terhadap pangan) tetapi juga dalam jangka panjang (insentif bagi produsen dalam memproduksi dan berinvestasi). Dari hasil-hasil penelitian tersebut, dapat dilihat bagaimana kenaikan harga pangan mempengaruhi daya beli masyarakat secara umum terutama untuk yang pendapatannya rendah. Seperti yang diungkapkan oleh Hertel, Ivanic, Preckel, dan Crandfield (2004) dalam Ivanic dan Martin (2008), alasan utama mengapa tingginya harga pangan berpengaruh besar terhadap masyarakat miskin adalah fakta bahwa kaum miskin membelanjakan sekitar $75 \%$ dari pendapatannya untuk membeli bahan pangan pokok.

\section{METODE PENELITIAN}

\section{Tempat dan Waktu Penelitian}

Kajian tentang daya beli masyarakat terhadap bahan pangan pokok dilaksanakan di wilayah Kabupaten Halmahera Tengah. Waktu pelaksanaan kajian, yakni dari bulan Februari sampai dengan bulan Mei 2018, dengan periode analisis tahun 2009 sampai dengan bulan Maret tahun 2018.

\section{Pengumpulan Data}


Jurnal Penelitian Humano, Vol. 9 No. 2 Edisi November 2018

Dalam rangka pelaksanaan dan publikasi BPS. Data yang pengumpulan data penelitian, diperlukan meliputi :

dilakukan dengan cara terbuka dan

1. Harga bulanan dan tahunan melakukan tiga tahap kegiatan sebagai berikut. Pertama, proses memasuki lapangan (getting in). Kedua, ketika berada di lapangan (getting along). Dan ketiga, mengumpulkan data (logging the data). Kajian ini menggunakan dua sumber data, Data primer diperoleh dengan beberapa cara, seperti penggunaan wawancara mendalam (in-depth interview, melalui key persons) dan investigasi serta melakukan Focus Group Discussion (FGD) dengan kelompok masyarakat. Sedangkan data sekunder didapatkan dengan melakukan studi dokumen yang berasal dari departemen pemerintah, lembaga riset, data dari BPS (Badan Pusat Statistik) dan lainlain. Dari kedua sumber data tersebut diharapkan diperoleh data yang lebih lengkap.

\section{Jenis dan Sumber Data}

Jenis data yang digunakan dalam penelitian ini adalah data primer dan data sekunder time series dengan periode tahun 2009 s,d, Maret 2018 yang diperoleh dari hasil wawancara sembilan komoditi pangan yang memiliki pangsa pengeluaran terbesar dalam konsumsi rumah tangga (berdasarkan SUSENAS) yang terdiri dari: beras, gula pasir, tepung terigu, minyak goreng, ikan segar, daging ayam, daging sapi, susu kental manis dan telur.

2. Volume / Jumlah komoditi pangan yang dikonsumsi.

3. Pendapatan masyarakat berpenghasilan rendah, yang diproxy oleh upah upah bulanan Tani, upah bulanan Buruh Bangunan, upah bulanan Karyawan, gaji pokok per bulan Pegawai Negeri Sipili (PNS) golongan II, dan pendapatan bulanan Wirausaha.

4. Pangsa pengeluaran untuk konsumsi bahan pangan pokok yang diperoleh dari hasil survei Susenas BPS.

\section{Metode Analisis Data}

\section{Analisis Deskriptif}

Analisis deskriptif digunakan untuk memberikan gambaran secara 
Jurnal Penelitian Humano, Vol. 9 No. 2 Edisi November 2018

mendetail tentang perkembangan harga bahan pangan pokok yang dianalisa maupun gambaran tentang perkembangan pendapatan dari masing-masing upah upah bulanan Tani, upah bulanan Buruh Bangunan, upah bulanan Karyawan, gaji pokok per bulan Pegawai Negeri Sipili (PNS) golongan II, dan pendapatan bulanan Wirausaha di Kabupaten Halmahera Tengah. Analisis ini menggunakan pendekatan tabulasi dan grafik.

\section{Analisis Rasio Pendapatan terhadap}

\section{Harga Pangan}

Rasio pendapatan terhadap harga pangan (RPH) merupakan salah satu metode untuk mengukur daya beli masyarakat secara umum. Metode ini

\section{Analisis Rasio Pendapatan Terhadap Indeks Harga Bahan pangan pokok}

Rasio pendapatan terhadap indeks harga bahan pokok digunakan untuk mengukur tingkat daya beli Dimana $\mathrm{IB}=$ Indeks Bahan pangan

$\mathrm{W}=$ bobot tiap

Menghitung rasio pendapatan terhadap indeks bahan pangan pokok dapat membantu mengukur tingkat daya beli masyarakat relatif terhadap harga komoditi tertentu (dalam hal ini 9 bahan pokok) seiring dengan perubahan tingkat pendapatan sebagai berikut (Resnia, 2012):

$$
R P H_{t}=\frac{I_{j t}}{P_{i t}}
$$

Dimana : $\quad$ RPH $=$ Rasio pendapatan terhadap harga komoditi

$\mathrm{P} \quad=$ Harga komoditi

I = Pendapatan

$\mathrm{i}=$ Jenis komoditi bahan pangan pokok

$\mathrm{j}=$ Upah Tani, Buruh Bangunan, Karyawan, gaji PNS, dan penghasilan Wirausaha $\mathrm{t}=$ Periode waktu (tahun)

masyarakat relatif terhadap perubahan harga 9 bahan pokok (Resnia, 2012):

$$
\begin{aligned}
& I B_{t}=\frac{\sum P_{i t} \cdot W_{i t}}{\sum P_{i o} \cdot W_{i o}} \mid \quad \text { dan } \\
& W_{i t}=\frac{\text { Pangsa Pengeluaran }_{i}}{\text { DPangsa Pengeluaran }}
\end{aligned}
$$

$\mathrm{t}=$ periode tertentu

$\mathrm{o}=$ periode tahun dasar

sehingga dihasilkan Indeks Daya Beli (IK) dimana masing-masing 
pendapatan dibagi dengan $\mathrm{IBt}$ sehingga dihasilkan ukuran atau tingkat daya beli terhadap bahan pangan pokok. IK dapat dihitung dengan formula berikut :

$$
I K_{t}=\frac{I_{j t}}{I B_{t}}
$$

Dimana $\mathrm{IK}=$ Indeks Daya Beli

(Daya beli)

\section{Pangsa Pengeluaran Rumah \\ Tangga, Perkembangan Harga \\ Bahan Pangan Pokok Dan \\ Pendapatan Masyarakat Di \\ Kabupaten Halmahera Tengah}

\section{Pangsa Pengeluaran Rumah Tangga Terhadap Bahan Pangan \\ Pokok}

Salah satu variabel ekonomi yang bisa dijadikan sebagai indikator terpenuhinya kebutuhan dasar adalah adanya peningkatan pangsa pengeluaran setiap rumah tangga masyarakat atas bahan makanan maupun bukan bahan makanan. Sesuai hasil analisis yang dilakukan terhadap kelompok responden (lihat Gambar 1), dari seluruh pengeluaran yang dilakukan oleh rumah tangga, teridentifikasi bahwa pangsa pengeluaran rata-rata per bulan untuk makanan mencapai 34,94\%.

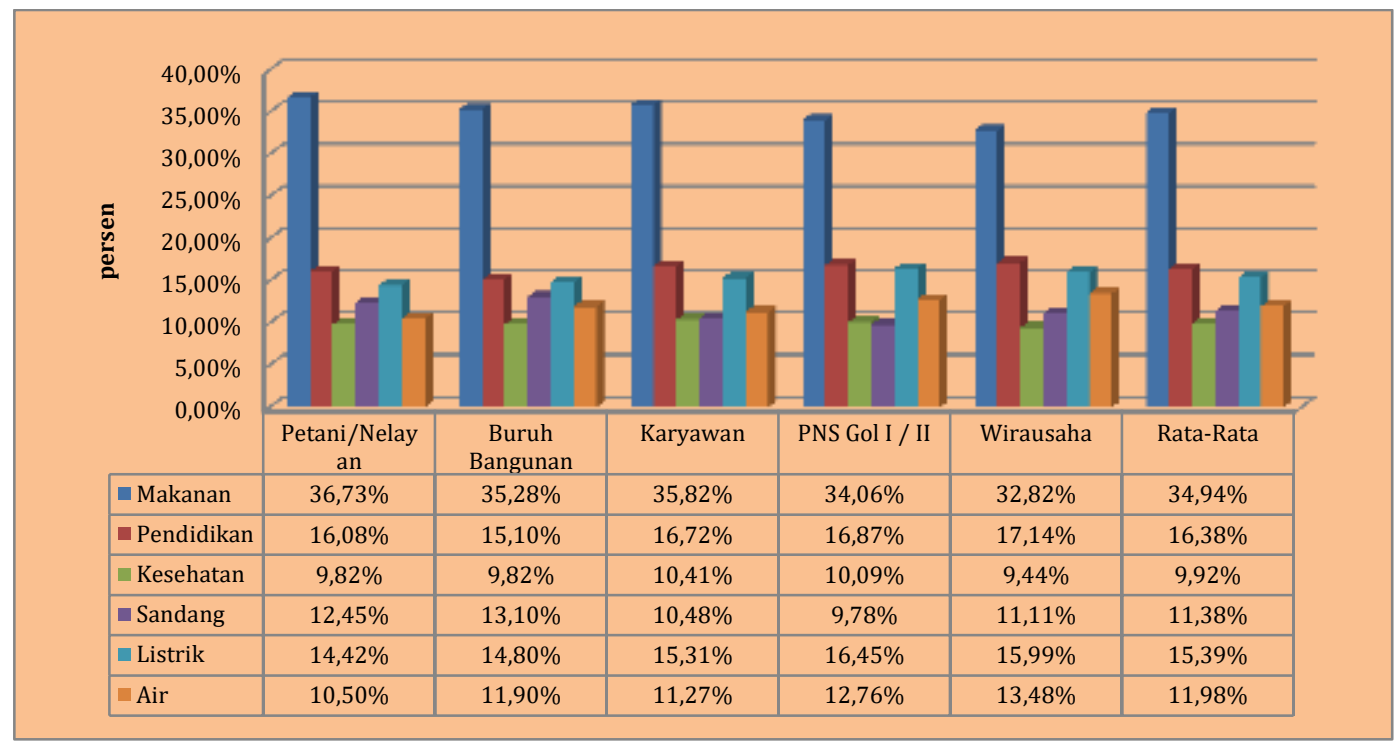

Sumber : Hasil Analisis, 2018.

Gambar 1.Alokasi Pengeluaran Rata-Rata Per Bulan Menurut Kelompok Barang dan Kelompok Masyarakat di Kabupaten Halmahera Tengah

Secara spesifik dalam minyak goreng, ikan, daging ayam, konsumsi bahan makanan khususnya daging sapi, susu kental manis dan konsumsi bahan pangan pokok telur, terdapat perbedaan yang berupa beras, gula, tepung terigu, signifikan dalam pangsa pengeluaran 
pada setiap bahan pangan pokok.

Proporsi pengeluaran rumah tangga masyarakat terhadap bahan pangan pokok teralokasi untuk memenuhi kebutuhan beras mencapai 12,6\% dan diikuti oleh pangan ikan segar sebesar $6,19 \%$. Sedangkan konsumsi daging sapi sebagai sumber protein hewani hanya mendapatkan proporsi $0,3 \%$. Secara terinci disajikan dalam Gambar 2 berikut.

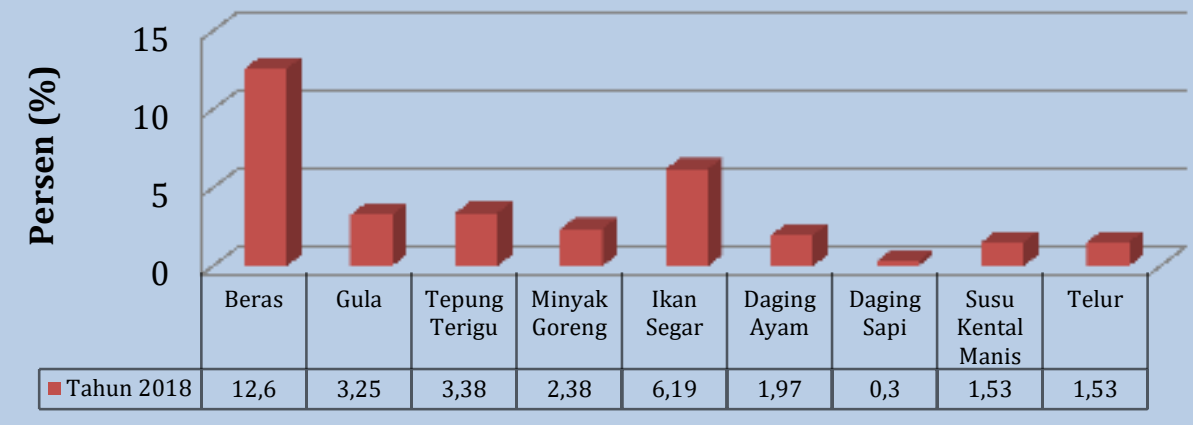

Sumber : Hasil Analisis Data Primer, 2018. Data Diolah.

Gambar 2.Pengeluaran Rumah Tangga Terhadap Bahan Pangan Pokok di Kabupaten Halmahera Tengah

\section{Perkembangan Harga Bahan Pangan Pokok}

Perbedaan dan fluktuasi harga bahan pangan pokok pada setiap wilayah sangat dipengaruhi oleh berbagai faktor diantaranya adalah biaya produksi dan karakteristik bahan pangan, tingkat persediaan, maupun pola dan rantai distribusinya. Kondisi faktual perkembangan harga bahan pangan pokok di Kabupaten Halmahera Tengah sepanjang periode tahun 2009 hingga bulan Maret tahun 2018 dapat dilihat dalam Tabel 1 berikut. Dari ke-9 (sembilan) bahan pangan pokok yang dikonsumsi selama 9 (sembilan) tahun terakhir, harga tertinggi terjadi pada pangan daging sapi dan diikuti oleh daging ayam, ikan segar, minyak goreng, gula pasir, beras, susu kental manis, tepung terigu dan telur. Dalam perkembangannya, harga bahan pangan pokok di Kabupaten Halmahera Tengah cenderung mengalam peningkatan. Harga tertinggi terjadi pada daging sapi dengan kenaikan $140 \%$ atau bergerak dari harga Rp. $50.000 .-/ \mathrm{kg}$ di tahun 2009 menjadi Rp. 120.000./kg di per bulan Maret Tahun 2018, dengan pertumbuhan rata-rata per tahun adalah $12,34 \%$. Kenaikan harga juga terjadi pada bahan pangan http://ejournal.unkhair.ac.id/index.php/humano 324 
Jurnal Penelitian Humano, Vol. 9 No. 2 Edisi November 2018

pokok lainnya, kecuali pada minyak

dibandingkan dengan tahun 2009, goreng yang mengalami penurunan dengan pertumbuhan rata-rata per harga $-4,20 \%$ di tahun 2018 tahun adalah $0,69 \%$.

Tabel 1.Perkembangan Harga Rata-rata Per Bahan Pangan Pokok di Kabupaten Halmahera Tengah, Tahun 2009 s.d. 2018.

\begin{tabular}{|c|c|c|c|c|c|}
\hline Tahun & $\begin{array}{l}\text { Beras } \\
(\mathrm{Rp} / \mathrm{Kg})\end{array}$ & $\begin{array}{l}\text { Gula Pasir } \\
\text { (Rp/Kg) }\end{array}$ & $\begin{array}{c}\text { Tepung } \\
\text { Terigu } \\
(\mathrm{Rp} / \mathrm{Kg}) \\
\end{array}$ & \multicolumn{2}{|c|}{$\begin{array}{l}\text { Minyak } \\
\text { Goreng } \\
\text { (Rp/Kg) }\end{array}$} \\
\hline 2009 & 8,000 & 10,000 & 7,500 & \multicolumn{2}{|c|}{15,292} \\
\hline 2010 & 9,417 & 10,250 & 6,000 & \multicolumn{2}{|r|}{15,583} \\
\hline 2011 & 11,000 & 12,000 & 8,600 & \multicolumn{2}{|r|}{10,750} \\
\hline 2012 & 10,083 & 13,583 & 8,750 & \multicolumn{2}{|r|}{13,250} \\
\hline 2013 & 10,417 & 12,813 & 8,900 & \multicolumn{2}{|r|}{13,300} \\
\hline 2014 & 11,833 & 13,083 & 9,000 & \multicolumn{2}{|r|}{13,333} \\
\hline 2015 & 13,700 & 13,700 & 9,000 & \multicolumn{2}{|r|}{13,000} \\
\hline 2016 & 12,950 & 15,575 & 9,000 & \multicolumn{2}{|r|}{15,375} \\
\hline 2017 & 13,000 & 15,000 & 9,000 & \multicolumn{2}{|r|}{16,000} \\
\hline Jan-Mar 2018 & 13,800 & 15,000 & 10,300 & \multicolumn{2}{|r|}{14,650} \\
\hline Harga Rata-Rata & 11,420 & 13,100 & 8,605 & \multicolumn{2}{|r|}{14,053} \\
\hline $\begin{array}{l}\text { Pertumbuhan } 9 \\
\text { Tahun }\end{array}$ & $72.50 \%$ & $50.00 \%$ & $37.34 \%$ & \multicolumn{2}{|r|}{$-4.20 \%$} \\
\hline $\begin{array}{l}\text { Pertumbuhan Rata- } \\
\text { Rata }\end{array}$ & $6.66 \%$ & $4.88 \%$ & $4.71 \%$ & \multicolumn{2}{|c|}{$0.69 \%$} \\
\hline Tahun & $\begin{array}{c}\text { Ikan } \\
\text { Segar } \\
(\mathrm{Rp} / \mathrm{Kg})\end{array}$ & $\begin{array}{c}\text { Daging } \\
\text { Ayam } \\
(\mathrm{Rp} / \mathrm{Kg})\end{array}$ & $\begin{array}{c}\text { Daging } \\
\text { Sapi } \\
(\mathrm{Rp} / \mathrm{Kg})\end{array}$ & $\begin{array}{c}\text { Kental } \\
\text { manis } \\
(\mathrm{Rp} / \\
\text { Kaleng) }\end{array}$ & $\begin{array}{l}\text { Telur } \\
\text { (Rp/ } \\
\text { Butir) }\end{array}$ \\
\hline 2009 & 25,208 & 35,000 & 50,000 & 9,000 & 1,500 \\
\hline 2010 & 14,583 & 35,000 & 50,000 & 9,000 & 1,500 \\
\hline 2011 & 15,000 & 42,900 & 89,200 & 9,000 & 1,500 \\
\hline 2012 & 16,250 & 43,000 & 90,000 & 10,000 & 1,750 \\
\hline 2013 & 22,800 & 45,000 & 95,000 & 10,000 & 1,600 \\
\hline 2014 & 23,000 & 45,000 & 99,000 & 10,000 & 2,000 \\
\hline 2015 & 25,500 & 47,500 & 110,000 & 11,000 & 2,000 \\
\hline 2016 & 37,650 & 41,650 & 100,800 & 10,000 & 2,500 \\
\hline 2017 & 30,000 & 50,000 & 100,000 & 12,000 & 2,500 \\
\hline Jan-Mar 2018 & 46,650 & 60,000 & 120,000 & 12,000 & 1,650 \\
\hline Harga Rata-Rata & 25,664 & 44,505 & 90,400 & 10,200 & 1,850 \\
\hline $\begin{array}{l}\text { Pertumbuhan } 9 \\
\text { Tahun }\end{array}$ & $85.06 \%$ & $71.43 \%$ & $140.00 \%$ & $33.33 \%$ & $10.00 \%$ \\
\hline $\begin{array}{l}\text { Pertumbuhan Rata- } \\
\text { Rata }\end{array}$ & $11.55 \%$ & $6.75 \%$ & $12.34 \%$ & $3.56 \%$ & $2.68 \%$ \\
\hline
\end{tabular}

Sumber : Hasil Analisis, 2018.

Perkembangan

Pendapatan Masyarakat
Tingkat

Untuk kepentingan analisis, data pendapatan masyarakat di

Kabupaten Halmahera Tengah http://ejournal.unkhair.ac.id/index.php/humano 325 
Jurnal Penelitian Humano, Vol. 9 No. 2 Edisi November 2018

diklasifikasikan atas upah tani, upah buruh bangunan, upah karyawan, gaji pegawai negeri sipil (PNS) golongan I/II, dan pendapatan wirausaha yang diperoleh per bulan. Perkembangan pendapatan masyarakat di Kabupaten Halmahera Tengah dapat dilihat pada Gambar 3 berikut. Secara rata-rata sepanjang periode pengamatan 2009 s.d. 2018 , besarnya upah tani adalah Rp. 1.355.455.- per bulan dengan pertumbuhan rata-rata $6,79 \%$ per tahun. Upah rata-rata buruh bangunan adalah Rp. 1.784.422.- per bulan dengan pertumbuhan rata-rata $6,72 \%$. Upah rata-rata dari karyawan adalah sebesar Rp. 2.817.975.- per bulan dengan rata-rata pertumbuhan 5,31 per tahun. Kemudian gaji pokok PNS Gol. I/II secara rata-rata adalah $\mathrm{Rp}$. 2.226.848.- per bulan dengan pertumbuhan $7,03 \%$. Sedangkan pendapatan dari wirausaha secara rata-rata per bulan selama adalah sebesar Rp. 2.735.585.- dengan pertumbuhan rata-rata $5,89 \%$.

\begin{tabular}{|c|c|c|c|c|c|c|c|c|c|c|c|}
\hline \multirow{2}{*}{\multicolumn{2}{|c|}{ 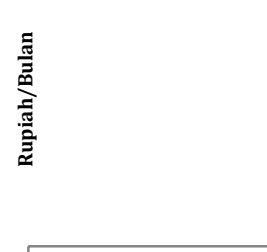 }} & \multicolumn{10}{|c|}{${ }^{2}=$} \\
\hline & & 2009 & 2010 & 2011 & 2012 & 2013 & 2014 & 2015 & 2016 & 2017 & $\begin{array}{c}\text { Jan - Mar } \\
2018 \\
\end{array}$ \\
\hline \multicolumn{2}{|c|}{$\longrightarrow$ Tani } & Rp1.000.0 & Rp1.100.0 & Rp1.200.0 & Rp1.250.0 & Rp1.275.0 & Rp1.300.0 & Rp1.500.0 & Rp1.525.0 & Rp1.613.4 & Rp1.791.1 \\
\hline \multicolumn{2}{|c|}{-Buruh Bangunan } & Rp1.250.0 & Rp1.300.0 & Rp1.450.0 & $\mathrm{Rp} 1.750 .0$ & Rp1.825.0 & $\mathrm{Rp} 1.850 .0$ & Rp1.900.0 & Rp2.139.7 & Rp2.168.6 & Rp2.210.8 \\
\hline \multicolumn{2}{|c|}{ - Karyawan } & Rp2.200.0 & Rp2.300.0 & Rp2.450.0 & $\mathrm{Rp} 2.650 .0$ & Rp2.750.0 & Rp2.898.0 & Rp3.000.0 & Rp3.106.1 & Rp3.325.5 & Rp3.500.0 \\
\hline \multicolumn{2}{|c|}{-PNS } & Rp1.586.5 & Rp1.644.2 & Rp1.799.5 & Rp2.100.4 & Rp2.231.9 & Rp2.413.1 & Rp2.440.3 & Rp2.569.4 & Rp2.586.7 & Rp2.896.4 \\
\hline \multicolumn{2}{|c|}{$\mp$ Wirausaha } & Rp2.100.0 & Rp2.300.0 & Rp2.456.0 & Rp2.506.5 & Rp2.597.0 & Rp2.691.0 & Rp2.830.0 & Rp3.072.0 & Rp3.296.9 & Rp3.506.3 \\
\hline Rata-rata & \multicolumn{2}{|c|}{$\begin{array}{c}\text { Petani } \\
\text { Rp } 1,355,455\end{array}$} & \multicolumn{3}{|c|}{$\begin{array}{c}\text { Buruh Bangunan } \\
\text { Rp 1,784,422 }\end{array}$} & \multicolumn{2}{|c|}{$\begin{array}{c}\text { Karyawan } \\
\text { Rp } 2,817,975 \\
\end{array}$} & \multicolumn{2}{|c|}{$\begin{array}{c}\text { PNS Gol I/II } \\
\operatorname{Rp} 2,226,848\end{array}$} & \multicolumn{2}{|c|}{$\begin{array}{c}\text { Wirausaha } \\
\text { Rp } 2,735,585\end{array}$} \\
\hline
\end{tabular}

Sumber : Hasil Analisis, 2018.

Gambar 3.Perkembangan Pendapatan Masyarakat di Kabupaten Halmahera Tengah Tahun 2014 s.d. 2018 Bulan Maret

\section{Daya Beli Masyarakat Dengan Indikator Rasio Pendapatan Terhadap Harga Pangan Pokok Di Kabupaten Halmahera Tengah}

Indeks daya beli berdasarkan rasio pendapatan terhadap harga dari masing-masing bahan pangan pokok mengasumsikan bahwa dimisalkan ketika pendapatan rumah tangga tertentu dialokasikan secara keseluruhan terhadap salah satu bahan pangan, maka dapat diketahui jumlah bahan pangan yang dapat dibeli berdasarkan kemampuan pendapatan rumah tangga untuk 
Jurnal Penelitian Humano, Vol. 9 No. 2 Edisi November 2018

mengkompensasi harga dari bahan pangan tertentu, sehingga dapat diketahui indeks daya beli setara konsumsi bahan pangan pokok tersebut.

Diukur dengan setara konsumsi masing-masing bahan pangan pokok, daya beli masyarakat di Kabupaten Halmahera Tengah cenderung berfluktuatif sepanjang periode analisis tahun 2009 hingga bulan Maret tahun 2018. Secara keseluruhan pada ke-9 bahan pangan pokok yang dikonsumsi, daya beli masyarakat paling besar dinikmati oleh kelompok masyarakat karyawan dan diikuti oleh kelompok wirausaha, PNS gol I/II, buruh bangunan, dan petani. Perbedaan dan fluktuasi daya beli masyarakat disebabkan oleh perubahan tingkat harga pada setiap bahan pangan pokok yang tidak mampu dikompensasi oleh perubahan pendapatan pada setiap kelompok masyarakat. Hasil analisis terhadapa daya beli masyarakat dengan indikator rasio pendapatan terhadap bahan pangan pokok di Kabupaten Halmahera Tengah dapat disajikan secara ringkas dalam Gambar 4 berikut.
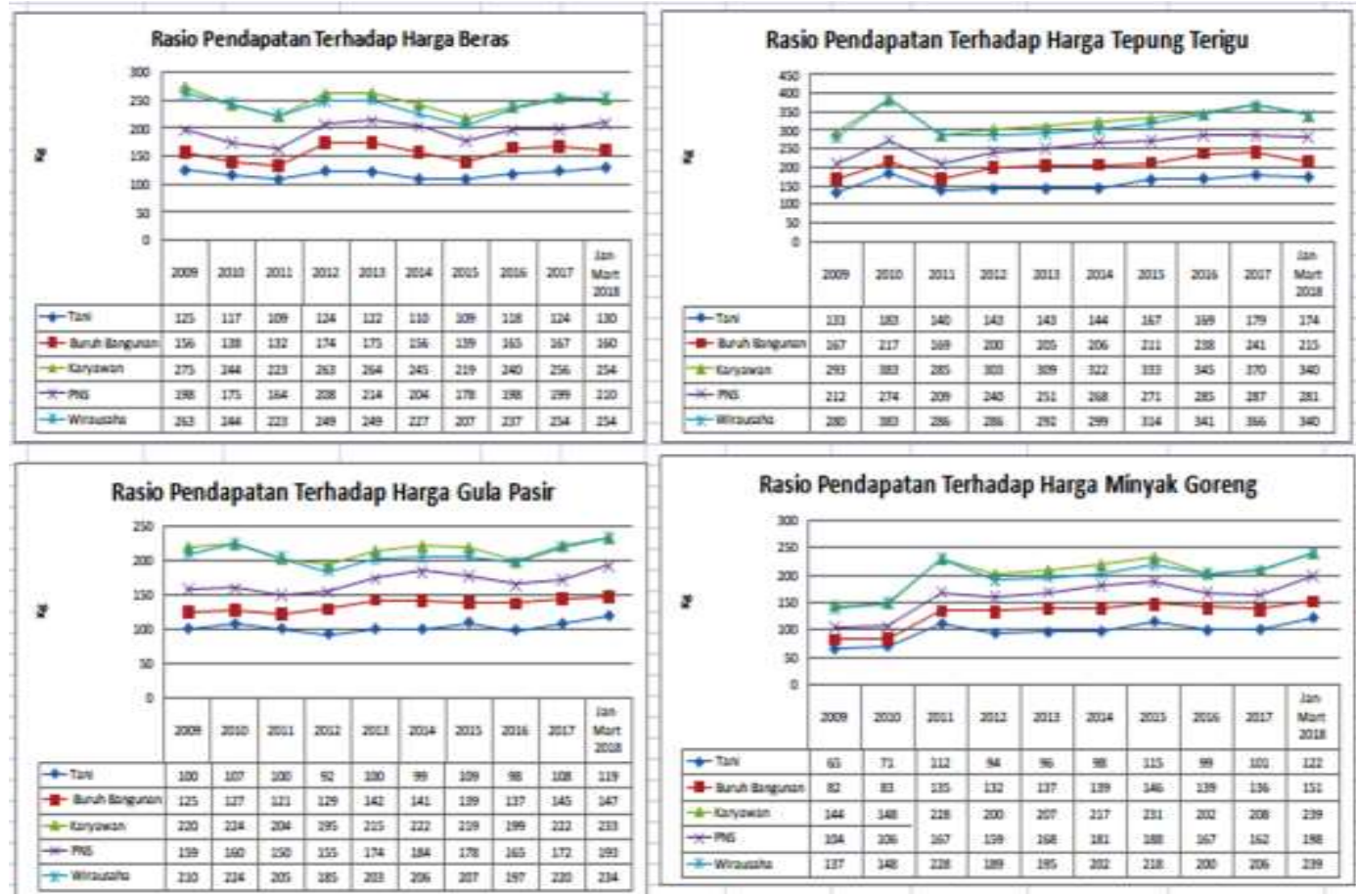

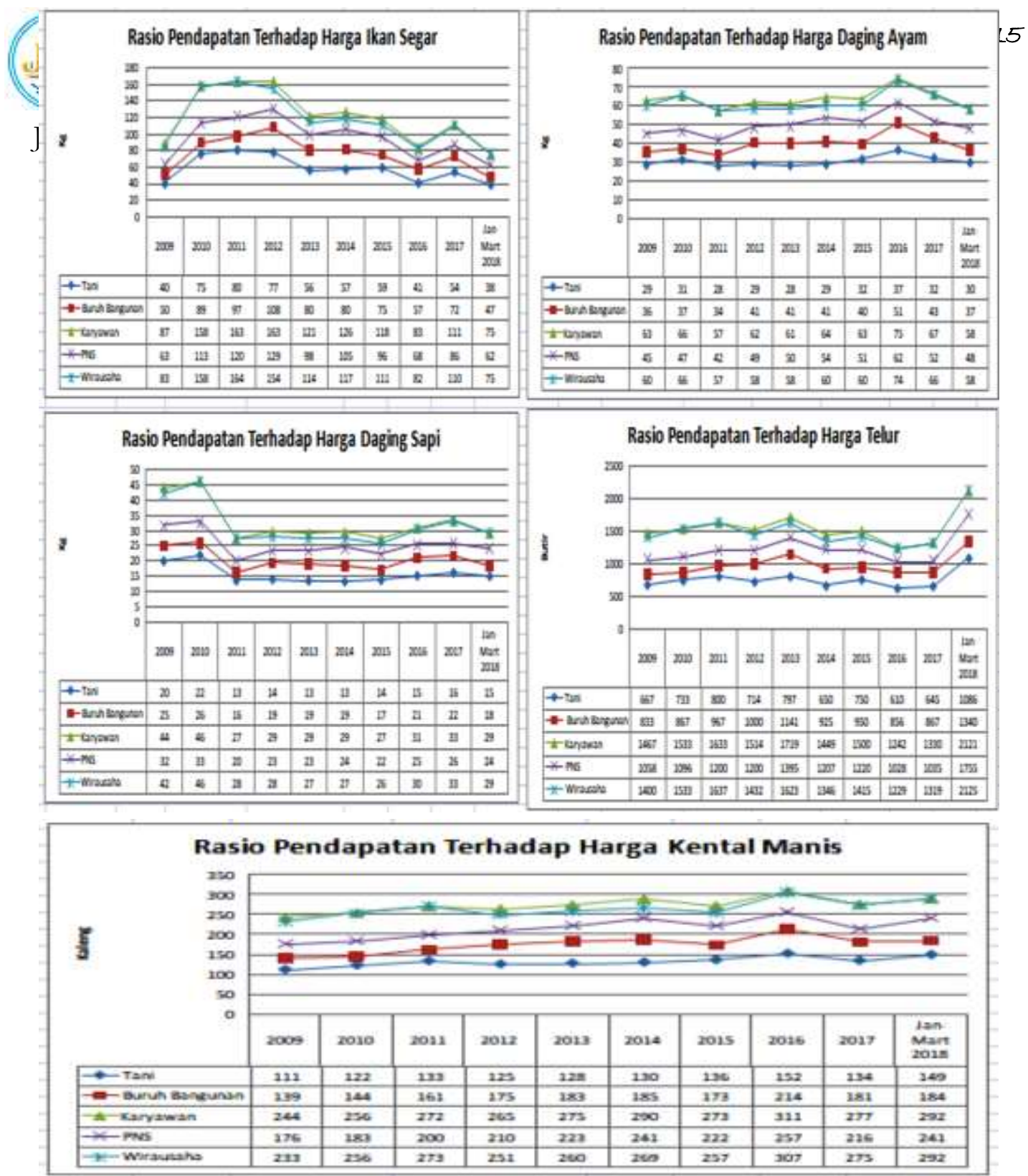

Sumber : Hasil Analisis, 2018-12-25

Gambar 4.Daya Beli Masyarakat Dengan Inddikator Rasio Pendapatan Terhadap Harga Bahan Pangan Pokok di Kabupaten Halmahera Tengah, Tahun 2009 s.d. 2018

Setara dengan konsumsi beras, daya beli masyarakat mengalami penurunan pada tahun 2010 hingga 2011 dan pada tahun 2013 hingga tahun 2015. Rata-rata daya beli petani setara konsumsi beras adalah sebesar $119 \mathrm{~kg}$ yang memposisikan petani sebagai kelompok dengan daya beli terendah dibandingkan kelompok masyarakat lainnya. Untuk buruh bangunan, daya beli rata- rata setara konsumsi beras adalah $156 \mathrm{~kg}$. Untuk karyawan, daya beli rata-rata adalah $241 \mathrm{~kg}$ setara konsumsi beras. Untuk PNS gol I/II, daya beli rata-rata setara konsumsi beras adalah $195 \mathrm{~kg}$. Sedangkan kelompok masyarakat yang memiliki daya beli tertinggi dinikmati oleh karyawan dengan daya beli rata-rata setara konsumsi beras sebesar $248 \mathrm{~kg}$. Kemudian http://ejournal.unkhair.ac.id/index.php/humano 328 
Jurnal Penelitian Humano, Vol. 9 No. 2 Edisi November 2018

setara konsumsi gula pasir, peningkatan daya beli masyarakat hanya terjadi pada tahun 2013, tahun 2017 dan tahun2018 per bulan Januari hingga Maret. Sedangkan pada tahun 2011 dan tahun 2016, seluruh kelompok masyarakat mengalamai penurunan daya beli setara konsumsi gula pasir secara serempak. Daya beli rata-rata setara konsumsi gula pasir adalah untuk petani sebesar $\quad 103 \mathrm{~kg}$, untuk buruh bangunan sebesar 135 kg, untuk karyawan sebesar 215 kg, untuk PNS gol I/II sebesar 169 kg, dan untuk wirausaha sebesar $209 \mathrm{~kg}$.

Selanjutnya diukur setara konsumsi tepung terigu, daya beli rata-rata setara konsumsi tepung terigu adalah untuk petani sebesar $158 \mathrm{~kg}$, untuk buruh bangunan sebesar $207 \mathrm{~kg}$, untuk karyawan sebesar $328 \mathrm{~kg}$, untuk PNS gol I/II sebesar $258 \mathrm{~kg}$, dan untuk wirausaha sebesar 319 kg. Daya beli petani, buruh bangunan, PNS gol I/II dan wirausaha mengalami penurunan pada tahun 2011 dan tahun 2018 per bulan Januari hingga Maret, sedangkan karyawan hanya mengalami penurunan daya beli pada tahun 2018 per bulan Januari hingga Maret. Kemudian setara konsumsi minyak goreng, daya beli seluruh kelompok masyarakat yang dianalisis mengalami penurunan pada tahun 2012 dan tahun 2016 , sedangkan pada tahun lainnya terjadi peningkatan daya beli. Daya beli rata-rata setara konsumsi minyak goreng adalah untuk petani sebesar $97 \mathrm{~kg}$, untuk buruh bangunan sebesar 128 kg, untuk karyawan sebesar 202 $\mathrm{kg}$, untuk PNS gol I/II sebesar $160 \mathrm{~kg}$, dan untuk wirausaha sebesar $196 \mathrm{~kg}$.

Daya beli diukur setara konsumsi ikan segar oleh masyarakat di Kabupaten Halmahera Tengah cenderung berkejolak dan menurun sepanjang tahun 2013 hingga tahun 2018 per bulan Januari hingga Maret. Dengan besarnya pendapatan dan perubahan harga yang dihadapi, daya beli rata-rata petani setara konsumsi ikan segar sebesar $58 \mathrm{~kg}$. Kemudian untuk buruh bangunan setara $75 \mathrm{~kg}$, untuk karyawan setara 120 kg, untuk PNS gol I/II setara $94 \mathrm{~kg}$, dan wirausaha dengan daya beli setara 117 kg konsumsi ikan segar. Sama halnya dengan ikan segar, daya beli masyarakat setara konsumsi daging ayam juga cenderung berfluktuasi menurun pada tahun 2011, tahun 2013, tahun 2015, dan 2017 hingga 
Jurnal Penelitian Humano, Vol. 9 No. 2 Edisi November 2018

tahun 2018. Rata-rata daya beli

Petani setara konsumsi daging ayam adalah $30 \mathrm{~kg}$, daya beli buruh bangunan setara $40 \mathrm{~kg}$, daya beli karyawan setara $64 \mathrm{~kg}$, daya beli PNS gol I/II setara $50 \mathrm{~kg}$ dan daya beli wirausaha setara konsumsi $62 \mathrm{~kg}$ daging ayam.

Untuk daya beli setara konsumsi daging sapi, daya beli masyarakat pada umumnya cenderung stabil dan hanya mengalami penurunan pada tahun 2011 dan tahun 2018. Ketika seluruh pendapatan dikompensasikan untuk konsumsi daging sapi, teridentifikasi bahwa daya beli petani sebesar $16 \mathrm{~kg}$, daya beli buruh bangunan sebesar 20 kg, daya beli karyawan sebesar 33 $\mathrm{kg}$, daya beli PNS gol I/II sebesar 25 $\mathrm{kg}$, dan daya beli wirausaha sebesar $32 \mathrm{~kg}$. Demikian juga jika daya beli yang diukur setara dengan konsumsi susu kental manis maupun telur, bahwa daya beli tertinggi dinikmati oleh karyawan dengan daya beli setara konsumsi susu kental manis adalah sebesar 275 kaleng dan untuk telur setara 1551 butir. Sedangkan daya beli terendah setara konsumsi susu kental manis dan telur, dirasakan oleh petani dengan daya beli setara konsumsi susu kental manis adalah 132 kaleng dan untuk telur setara 745 butir.

Sesuai dengan hasil analisis tersebut, daya beli masyarakat sangat rendah ketika diukur setara dengan konsumsi daging sapi. Sedangkan daya beli masyarakat sangat tinggi ketika diukur setara dengan konsumsi telur. Tinggi atau rendahnya daya beli masyarakat di Kabupaten Halmahera Tengah atas setiap bahan pangan yang dikonsumsi sangat dipengaruhi oleh tingkat harga yang berlaku di pasar atas bahan pangan. Disisi lain, pendapatan masyarakat tidak terlalu mengalami perubahan yang signifikan untuk melakukan penyesuaian atas perubahan harga bahan pangan. Dari seluruh bahan pangan yang dianalisis, daya beli masyarakat pada tahun 2018 yang jauh lebih kecil dibandingkan tahun 2009, terjadi pada konsumsi bahan pangan daging sapi dengan penurunan daya beli rata-rata pada seluruh kelompok masyarakat yang dianalisis mencapai $22,32 \%$.

\section{Daya Beli Masyarakat Dengan \\ Indikator Rasio Pendapatan Terhadap Indeks Harga Pangan Pokok Di Kabupaten Halmahera Tengah}

Berbeda dengan indikator sebelumnya, daya beli masyarakat 
Jurnal Penelitian Humano, Vol. 9 No. 2 Edisi November 2018

terhadap bahan pangan pokok pada pendekatan ini tidak diukur menurut masing-masing bahan pangan pokok. Daya beli dalam pendekatan ini diukur dengan membandingkan tingkat pendapatan setiap kelompok masyarakat dengan indeks harga yang berlaku secara keseluruhan pada bahan pangan pokok. Tahapan terpenting dalam analisis daya beli masyarakat dengan pendekatan ini adalah, pertama menghitung indeks bahan pangan pokok dengan mangkalkulasi data pangsa pengeluaran penduduk dan harga dari setiap bahan pangan pada setiap periode. Kedua menghitung rasio pendapatan terhadap indeks bahan pangan pokok yang telah dihitung sebelumnya. Berikut pada Gambar 5 disajikan indeks harga bahan pangan pokok yang telah dianalis.

Dengan menjadikan tahun 2009 sebagai tahun dasar analisis, indeks harga bahan pangan pokok mengalami penurunan pada tahun 2010 sebesar 11,41 \% atau berubah dari 100 menjadi 88,59. Sedangkan pada tahun 2011 hingga bulan Maret tahun 2018, indeks harga bahan pangan pokok terus mengalami peningkatan. Pada tahun 2018 per bulan Januari hingga Maret, indeks harga bahan pangan pokok mengalami peningkatan hingga 67,63 $\%$ atau berubah dari 100 di tahun 2009 menjadi 167,63 di tahun 2018.

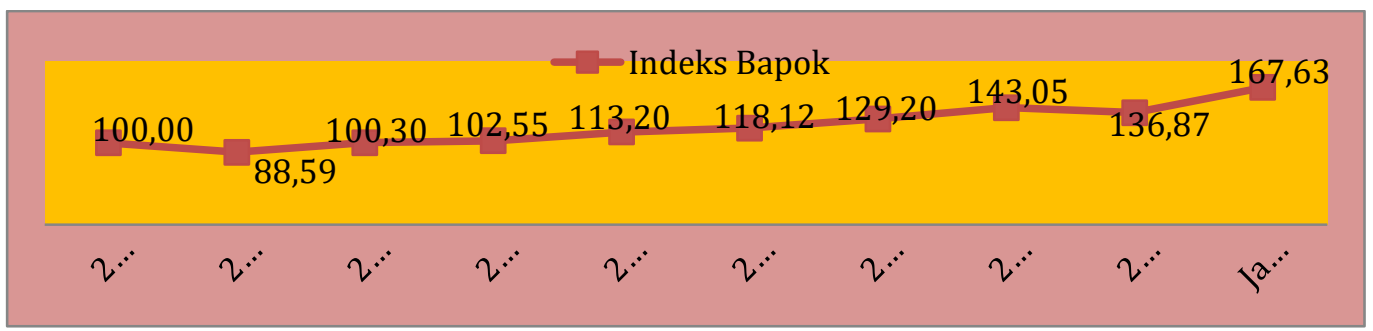

Sumber : Hasil Analisis, 2018.

Gambar 5.Perkembangan Indeks Harga Bahan Pangan Pokok di Kabupaten Halmahera Tengah Tahun 2009 s.d. 2018

Dengan mendasari pada pokok, sebagaimana tersaji pada indeks harga bahan pangan pokok Gambar 6 berikut. Hasil analisis pada Gambar 5 di atas, selanjutnya menjelaskan bahwa daya beli dapat dianalisis daya beli masyarakat masyarakat terbesar dinikmati oleh di Kabupaten Halmahera Tengah karyawan dan wirausaha dan diikuti dengan indikator rasio pendapatan oleh PNS gol I/II, buruh bangunan terhadap indeks harga bahan pangan dan petani. Disaat indeks harga http://ejournal.unkhair.ac.id/index.php/humano 331 
Jurnal Penelitian Humano, Vol. 9 No. 2 Edisi November 2018

bahan pangan pokok pada tahun 2010 mengalami penurunan, daya beli masyarakat pada umumnya mengalami kenaikan di tahun 2010. Sedangkan pada tahun 2011, daya beli masyarakat kembali mengalami penurunan.

Kemudian pada tahun 2012 daya beli masyarakat secara keseluruhan kembali mengalami kenaikan meskipun pada tahun 2012 terjadi pula kenaikan pada indeks harga bahan pangan pokok. Kondisi ini disebabkan oleh kemampuan pendapatan masyarakat pada tahun 2012 yang mampu mengkompensasi perubahan indeks harga yang terjadi. Dibandingkan dengan tahun 2009, daya beli yang dirasakan masyarakat pada tahun 2018 jauh lebih besar. Indeks daya beli petani pada tahun 2018 adalah 78,48, kemudian daya beli buruh bangunan sebesar 96,86, daya beli karyawan sebesar 153,35, daya beli PNS gol I/II sebesar 126,90, dan daya beli wirausaha sebesar 153,62.

\begin{tabular}{|c|c|c|c|c|c|c|c|c|c|c|}
\hline \multirow{2}{*}{$\frac{0}{\sqrt[3]{\pi}}$} & \multicolumn{10}{|c|}{ 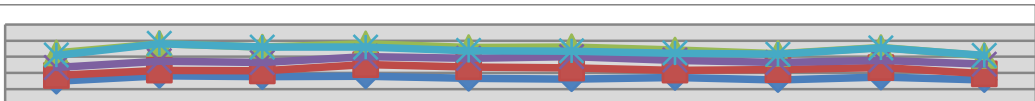 } \\
\hline & 2009 & 2010 & 2011 & 2012 & 2013 & 2014 & 2015 & 2016 & 2017 & $\begin{array}{c}\text { Jan- } \\
\text { Mar201 } \\
8\end{array}$ \\
\hline$\longrightarrow$ Tani & 73,44 & 91,19 & 87,87 & 89,53 & 82,72 & 80,83 & 85,27 & 78,30 & 86,57 & 78,48 \\
\hline$=$ Buruh Bangunan & 91,80 & 107,78 & 106,18 & 125,34 & 118,40 & 115,02 & 108,01 & 109,86 & 116,36 & 96,86 \\
\hline- Karyawan & 161,57 & 190,68 & 179,40 & 189,79 & 178,41 & 180,19 & 170,53 & 159,48 & 178,44 & 153,35 \\
\hline$\because$ PNS & 116,52 & 136,31 & 131,77 & 150,43 & 144,80 & 150,03 & 138,72 & 131,92 & 138,80 & 126,90 \\
\hline$\approx$ Wiraus & 154,23 & 190,68 & 179,84 & 179,52 & 168,48 & 167,31 & 160,87 & 157,73 & 176,91 & 153,62 \\
\hline
\end{tabular}

Sumber : Hasil Analisis, 2018.

Gambar 6. Indeks Daya Beli Masyarakat Dengan Indikator Rasio Pendapatan Terhadap Indeks Harga Bahan Pangan Pokok di Kabupaten Halmahera Tengah Tahun 2009 s.d. 2018

Pada dasarnya daya beli harga tetap stabil dan mampu masyarakat di Kabupaten Halmahera dijangkau oleh masyarakat dapat Tengah mengalami penurunan disaat dilakukan melalui peningkatan terjadi kenaikan harga bahan pangan pokok yang tidak diimbangi dengan peningkatan pendapatan dengan persentase yang lebih besar. Upaya perbaikan daya beli dapat dimulai dari kedua variabel tersebut baik harga pangan maupun pendapatan masyarakat. Menjaga agar tingkat kapasitas produksi domestik atau dalam wilayah, perbaikan rantai distribusi, peningkatan persediaan pangan, maupun pengendalian harga di pasar dari tindakan spekulasi. Kemudian dari aspek pendapatan, upaya yang dapat dilakukan diantaranya melalui penyadaran, 
Jurnal Penelitian Humano, Vol. 9 No. 2 Edisi November 2018

pendampingan dan peningkatan kapasitas dari Petani maupun Buruh Bangunan, perluasan kesempatan kerja terutama pada sektor informal melalui tumbuh kembang kewirausahaan di masyarakat. Lebih penting lagi, dengan karakteristik wilayah Kabupaten Halmahera Tengah sebagai bagian dari di Provinsi Maluku Utara yang merupakan wilayah kepulauan maka konektivitas antar pulau dan wilayah perlu menjadi prioritas melalui daya dukung infrastruktur yang optimal.

\section{PENUTUP}

Setelah melalui proses analisis dan pembahasan terkait daya beli masyarakat terhadap bahan pangan pokok di Kabupaten Halmahera Tengah, maka dapat dikemukakan beberapa kesimpulan sebagai berikut :

1. Pengeluaran rumah tangga masyarakat di Kabupaten Halmahera Tengah menurut kelompok barang, secara umum lebih besar teralokasi pada pengeluaran untuk bahan makanan, pendidikan, listrik dan sandang. Lebih spesifik, pengeluaran untuk bahan makanan khususnya bahan pangan pokok lebih besar dialokasikan untuk pemenuhan konsumsi beras dan ikan segar, diikuti oleh konsumsi tepung terigu, gula dan minyak goreng. Sedangkan alokasi pengeluaran untuk konsumsi pangan pokok yang bersumber dari hewani antara lain daging ayam, susu, telur dan daging sapi masih sangat rendah. Harga bahan pangan pokok di Kabupaten Halmahera Tengah selama periode pengamatan tahun 2009 hingga tahun 2018 bulan Januari - Maret, cenderung mengalami kenaikan pada kisaran $2 \%-12$ $\%$ dan itu terjadi pada seluruh bahan pangan pokok kecuali minyak goreng. Sedangkan disisi lain, tingkat pendapatan masyarakat hanya mengalami perubahan pada kisaran $5 \%-7$ $\%$, dengan pendapatan tertinggi dinikmati oleh karyawan dan wirausaha dan sebaliknya pendapatan terendah dirasakan oleh petani. Hasil indept 
Jurnal Penelitian Humano, Vol. 9 No. 2 Edisi November 2018

interview dan analisis

menunjukkan bahwa keseluruhan

kelompok masyarakat terutama

petani dan buruh bangunan masih

mengeluhkan nilai pendapatan

yang masih kecil dibandingkan

nilai pengeluaran yang sangat

besar karena tingginya harga dan

tingkat kebutuhan yang terus meningkat.

2. Daya beli masyarakat di Kabupaten Halmahera Tengah dengan indikator rasio pendapatan terhadap masingmasing harga bahan pangan pokok cenderung berfluktuasi namun mengalami perbaikan yang signifikan pada tahun 2018 dibandingkan tahun 2009, kecuali daya beli yang diukur setara konsumsi daging sapi. Daya beli setara konsumsi daging sapi mengalami penurunan hingga $22,32 \%$ dikarenakan persentase kenaikan pendapatan kurang mampu mengkompensasi kenaikan harga daging sapi.

3. Diukur dengan indikator rasio pendapatan terhadap indeks harga bahan pangan pokok, daya beli masyarakat juga menunjukkan terjadi perbaikan di tahun 2018 dibandingkan tahun 2009, tetapi itu hanya terjadi pada petani, buruh bangunan, dan PNS gol I/II. Jika dibandingkan dengan tahun 2017, daya beli masyarakat pada tahun 2018 secara keseluruhan mengalami penurunan $12,38 \%$. Tingkat daya beli masyarakat di Kabupaten Halmahera Tengah dari ranking terendah secara berurut adalah dirasakan oleh kelompok masyarakat petani, diikuti oleh buruh bangunan, PNS gol I/II, wirausaha dan karyawan.

Sesuai dengan kesimpulan yang dikemukakan, maka terdapat beberapa hal yang dapat direkomendasikan melalui penelitian ini yaitu :

1. Pemerintah daerah harus dapat mengendalikan fluktuasi harga yang banyak berkontribusi terhadap inflasi daerah, khususnya harga komoditas pangan. Pengendalian harga tersebut dilakukan dengan memantau harga secara rutin dan 
Jurnal Penelitian Humano, Vol. 9 No. 2 Edisi November 2018

melakukan operasi pasar sehingga apabila terjadi kenaikan harga yang tidak wajar dapat segera menstabilkan harga tersebut.

2. Pemerintah dapat melakukan pengendalian terhadap harga pangan di pasar melalui penetapan batasan harga terendah (floor price) maupun batasan harga tertinggi (ceiling price).

3. Mengoptimalkan potensi yang dimiliki untuk meningkatkan produksi pangan dalam wilayah agar mampu memenuhi permintaan domestik dan mengurangi ketergantungan wilayah terhadap komoditas pangan impor dengan harapan tingkat harga pangan yang berlaku dipasar lebih dapat dikendalikan. Hal ini dapat dilakukan dengan memberikan insentif kepada petani maupun peternak agar tetap memproduksi bahan pangan.

4. Penambahan pemain baru (produsen) di pasar agar dapat membuat pasar lebih kompetitif dan pada akhirnya menurunkan harga.

5. Meningkatkan efisiensi distribusi bahan-bahan pangan pokok. Hal tersebut dapat dicapai dengan memperbaiki infrastruktur logistik, memangkas rantai distribusi dan mencegah terjadinya penimbunan stok.

6. Selain hal-hal tersebut di atas, pemerintah hendaknya dapat mengurangi dampak negatif kenaikan harga bahan-bahan pangan pokok melalui kebijakan subsidi (harga dan volume) untuk masyarakat berpenghasilan rendah yang tepat sasaran.

\section{DAFTAR PUSTAKA}

Aninomous. (2015). Kamus Besar. Diunduh tanggal 1 November 2015 dari http://www.kamusbesar.com/ 49814/daya-beli

Ariani, M. (2010). Analisis Konsumsi Pangan Tingkat Masyarakat Mendukung Pencapaian Diversifikasi Pangan. Gizi Indonesia 2010, 33(1):20-28.

BPS Halmahera Tengah. 2009-2018. Halmahera Tengah Dalam Angka. BPS Kabupaten Halmahera Tengah. Weda.

Departemen Perindustrian dan Perdagangan (Deperindag). (1998). Surat Keputusan Menteri Perdagangan dan 
Jurnal Penelitian Humano, Vol. 9 No. 2 Edisi November 2018

Perindustrian

115/MPP/KEP/2/1998

tentang Jenis Barang

Kebutuhan Pokok

Masyarakat. Diunduh tanggal

6 Agustus 2015 dari

http://www.kemenperin.go.id/

FAO. (2010). Agriculture and

Consumer Protection.

"Dimensions of Need-Staple

Foods: What Do People Eat?.

Diunduh tanggal 20 Agustus

2015 dari http://www.fao.org/

Firdaus, M. 2017. Menyikapi Gejolak

Harga Pangan. Fakultas

Ekonomi dan Manajemen,

Institut Pertanian Bogor.

Bogor. Diunduh tanggal 1

Maret 2018 dari

http://www.fem.ipb.ac.id/

Frankenberg, E., D. Thomas, and K.

Beegle. (1999). The Real Cost

of Indonesia's Economic

Crisis : Preliminary Findings

from the Indonesia Family

Life Surveys. Labor and

Population Program, RAND

Working Paper Series 99-04.

Galtier, F. (2009). How to Manage

Food Price Instability in

Developing Countries.

Working Paper Moisa N 5.

Seminar "How to Manage Agricultural Price Volatility", Agence Francaise Pour Le Developpement Paris (FRA).

Hanafie, R. 2010. Pengantar Ekonomi Pertanian. ANDI Offset. Yogyakarta.

Hidayah, N. (2011). Kesiapan Psikologis Masyarakat Pedesaan dan Perkotaan Menghadapi Diversifikasi Pangan Pokok. Jurnal
Humanitas Vol. Viii No.1 Januari 2011.

Ivanic, M. and W. Martin. (2008). Implications of Higher

Global Food Price for

Poverty in Low-Income

Countries. World Bank

Development Research

Group.

Jum'at, F. (2008). Penggunaan Metode Pohon Regresi Untuk Mengkaji Nilai Indeks Daya Beli di Jawa Barat. Skripsi Departemen Statistika Institutu Pertanian Bogor. Bogor.

Kementerian Perdagangan (2010). Peraturan Menteri

Perdagangan Republik Indonesia No. 03/MDAG/PER/1/2010 Tentang Rencana Strategis Kementerian Perdagangan Tahun 2010- 2014. Diunduh tanggal 10 September 2015 dari http://www.kemendag.go.id/i $\mathrm{d} /$ news/201 0 / 04 / 12 / p e r a $\mathrm{t}$ u r a n -me n t e r i perdagangan-republikindonesia-nomor-03mdagper12010-tentangrencanastrategis- kem.

Kementerian Pertanian. (2010). Rencana strategis Badan Ketahanan Pangan 20102014. Kementerian Pertanian Republik Indonesia. Kementerian Pertanian.

Nurkhayani, E. (2009). Analisis Permintaan Pangan dan Gizi di Indonesia. Tesis Pascasarjana Ilmu Ekonomi. Universitas Indonesia. Jakarta 
Jurnal Penelitian Humano, Vol. 9 No. 2 Edisi November 2018

Rachman, H. P.S.(2005). Metode Analisis Harga Pangan. Disampaikan pada Apresiasi Sistem Distribusi dan Harga Pangan oleh Badan Ketahanan Pangan di Pusat Manajemen Pengembangan SDM Pertanian, Ciawi-Bogor 3 - 5 Juli 2005. Pusat Analisis Sosial Ekonomi dan Kebijakan Pertanian. Bogor.

Resnia, R. (2012). Fluktuasi Harga Bahan Pangan Pokok dan Daya Beli Kelompok Masyarakat Berpendapatan Rendah. Buletin Ilmiah Litbang Perdagangan, Vol 6 No 2, Desember 2012. Jakarta

Saliem, H.P., M. Ariani, Y. Marisa dan T.B. Purwantini. (2002). Analisis Kerawanan Pangan Wilayah Dalam Perspektif Desentralisasi Pembangunan. Laporan Hasil Penelitian. Pusat Penelitian dan Pengembangan Sosial Ekonomi Pertanian.Bogor.

Setneg Republik Indonesia. (1996). Undang Undang No. 7 Tahun 1996 tentang Pangan. Diunduh tanggal 10 September 2015 dari http://www.setneg.go.id/

Setneg Republik Indonesia. (1996). Peraturan Pemerintah Republik Indonesia Nomor 68 Tahun $2002 \quad$ tentang Ketahanan Pangan. Diunduh tanggal 10 September 2015 dari http://www.setneg.go.id/

Setneg Republik Indonesia. (2012). Undang-Undang No 18 Tahun 2012 tentang Pangan. Diunduh tanggal 10
September 2015 dari http://www.setneg.go.id/

Sobri. (1999). Ekonomi Makro. BPFE-UGM. Yogyakarta

Sukardi. (2009). Konsep Daya Beli Masyarakat. Pusat Perbukuan Departemen Pendidikan Nasional. Diunduh tanggal 1 November 2015 dari http://dokumen.tips/document s/beberapa-factor-yangmempengaruhi-aya-belimasyarakat-yaitu.html

Sukirno, S. (2006). Makroekonomi. Raja Grafindo Persada. Jakarta. 